\title{
KONCEPCIA VYUČOVANIA GEOGRAFIE MIESTNEJ KRAJINY NA ZÁKLADNEJ ŠKOLE
}

\author{
Ivana Tomčíková
}

\begin{abstract}
The issue of the local landscape is connected to the whole system of geographic education of all levels. At primary school, teaching of geography of the local landscape is represented particularly in the 8th class. In majority of the schools, the traditional structure, based on components of the landscape, is often taught without much emphasis on context. However, the local landscape is the place where the pupils grow up and live, to which they have a relationship and which they also have known by their own experiences. Pupils identify with it and there is a certain emotional bond between them and this place. The aim of the article is to propose the conception of teaching geography of the local landscape. In the proposed concept, the local landscape is a place, which is important for pupils' further development (sense of place). It is a unique place which should be used to develop pupils' geographic thinking. However, it should be noted that when we want pupils to understand the local landscape, they must study it in broader contexts in relations with the space that surrounds it.
\end{abstract}

Keywords: local country, sense of place, primary school, geography, Slovakia

\section{Úvod}

V súčasnej spoločnosti je trend rýchleho tempa globalizácie. Ak však chce žiak pochopit' svet, musí v prvom rade porozumiet' domovu. $Z$ tohto dôvodu by sa vo vyučovaní geografie mala venovat' zvýšená pozornost' miestnej krajine, ktorá je žiakom blízka, nakol'ko v nej vyrastajú, chodia do školy, športujú - jednoducho v nej žijú.

Problematika miestnej krajiny je témou, ktorá sa prelína celým systémom geografického vzdelávania vo všetkých jej stupňoch. Miestna krajina je miesto, v ktorom žiaci žijú, ku ktorému majú vzt’ah, ktoré spoznávajú pomocou vlastných skúseností. Žiaci sa s ním stotožňujú, dávajú mu meno, existuje medzi nimi a týmto miestom isté citové puto.

Ciel'om príspevku je navrhnút' koncepciu vyučovania geografie miestnej krajiny. Miestna krajina je v navrhovanej koncepcii pre žiakov miestom, ktorého význam si uvedomujú pre svoj d’alší rozvoj (sense of place). Je to jedinečné miesto, ktoré treba využit' na rozvíjanie geografického myslenia žiakov. Ak však chceme, aby žiaci pochopili miestnu krajinu, musia ju študovat' $\mathrm{v}$ širších súvislostiach vo vzt'ahoch s priestorom, ktorý ho obklopuje. 
$\mathrm{V}$ príspevku tiež poukazujeme na postavenie geografie miestnej krajiny $\mathrm{v}$ školskom vzdelávacom systéme na základnej škole, popisujeme ciele a obsah geografie miestnej krajiny, definujeme pojem miestna krajina a charakterizujeme ho z priestorového, časového a didaktického hl'adiska.

\section{Teoreticko-metodologické východiská}

Ciel'om vyučovania na základných školách je rozvíjat' vedomosti, zručnosti a kompetencie žiakov využitel'né nielen v škole, ale aj v každodennom živote. Treba si ujasnit', ako sa vedomost' líši medzi informáciou na jednej strane a porozumením na druhej strane. Jednou z možností je uvažovat' o hierarchii. Fakty a informácie tvoria najnižší stupeň v hierarchii vedomostí. Často sú izolované a sami o sebe majú len malú hodnotu. Poskytujú však základ pre vyššie stupne myslenia, ktoré zahíňajú napr. analýzu či kritické myslenie (Scoffham, 2011).

Poznanie faktov je samo o sebe bezcenné bez zvládnutia schopnosti syntetizovat', integrovat' a hodnotit' (pri faktografických otázkach stačí len povrchné uvedomenie si obsahu). Žiaci sa musia naučit' premýšl'at', tvorit', zvažovat', hodnotit' a zodpovedat' za výsledky svojej práce. Tieto ciele možno splnit', ak tradičné vyučovanie, založené na memorovaní vel'kého množstva informácií, nahradíme vyučovaním zameraným na samostatnú a tvorivú činnost' žiakov na hodine (Tomčíková, 2017). Zmysluplné učenie je učenie, pri ktorom žiaci o novom poznatku uvažujú, zapájajú sa do diskusie, hl'adajú riešenia a vtedy sa stanú ich nové skúsenosti základom poznania.

Miestna krajina je tá čast' reálneho sveta, ktorá žiakov obklopuje od útleho detstva, geografické poznatky sú teda vel’mi úzko späté s praktickým životom. Práve vo vyučovaní geografie miestnej krajiny musí učitel' položit' dôraz na afektívne ciele a prostredníctvom nich dôjde aj $\mathrm{k}$ upevneniu a naplneniu kognitívnych ciel'ov u žiakov. Žiaci môžu konfrontovat' svoj obraz miestnej krajiny, jeho percepciu, s obrazmi iných (spolužiakov, učitel'a, autorov doplnkových informačných prameňov a pod.). V samotnom obsahu vyučovania sa môžu výraznejšie spolupodiel'at' na jeho utváraní, na koncepcii učiva, prezentovat' svoje skúsenosti a zážitky v miestnej krajine. Môžu sa tu prejavit' aj slabší žiaci samostatným riešením problémov, schopnost'ou hodnotit' javy z reálneho života (Madziková, 2004).

Formovanie názorov žiakov závisí od ich skúseností, miestna krajina je bránou pri poznávaní vzdialenejších krajín v časovo-priestorovej dimenzii. $\mathrm{Na}$ druhej strane, ak chceme, aby žiaci pochopili miestnu krajinu, musia ju študovat' v širších súvislostiach s priestorom, ktorý ju obklopuje. Dokonca sa neskúmajú len geografické poznatky, ale aj podmienky a príčiny javov, ich zmeny v čase a priestore, pričom ich pochopenie nie je možné bez integrácie s inými predmetmi (možno využívat' medzipredmetové vzt'ahy). 
Geograficky mysliet' znamená spôsob porozumenia svetu a odhalenie priestorových súvislostí medzi rôznymi miestami a mierkami (Nogová, 2016). V geografii rozlišujeme tri základné priestorové koncepty - priestor (space), miesto (place) a mierku (scale). Pojmy región a miesto patria ku klúčovým geografickým pojmom. Miesto je jedným z kardinálnych konceptov geografie (Matlovič, Matlovičová, 2015). Svet je možné poznat' cez miesta a to pomocou l'udskej percepcie a skúseností. Novou výzvou pre vzdelávací proces je preto učit' o miestach a regiónoch cez vzt'ah obyvatel'ov k danému miestu (Nogová, 2016).

Na základe týchto myšlienok sme navrhli koncepciu vyučovania geografie miestnej krajiny, kde kladieme dôraz na lokalizáciu (polohu), priestorové myslenie, ale aj na význam miestnej krajiny pre žiaka. Koncepcia nezahŕňa len súčasný stav miestnej krajiny, ale aj presah do minulosti (cez osobné skúsenosti, štúdium histórie) a budúcnosti (očakávania a zámery).

\section{Definovanie pojmu miestna krajina a zhodnotenie rôznych hl'adísk pri jej štúdiu}

Pojem miestna krajina nie je v didaktickej terminológii jednoznačný. Okrem miestnej krajiny sa pomerne často stretávame aj s pojmami lokálna krajina, miestna oblast', miestny región, mikroregión, ktoré sa chápu ako synonymá a autori ich charakterizujú z viacerých hl'adísk. Vzhl'adom na túto nejednotnost' je vel'mi dôležité okrem názorov odborníkov aj akceptovanie konkrétnych podmienok školy a skúseností žiakov.

Priestorové hl'adisko miestnej krajiny je podmienené vel'kost'ou regionálnej geografickej mierky. Pojem miestna krajina sa prvýkrát vyskytuje vo vlastivede, kde je charakterizovaná ako obec, resp. čast' obce, a jej okolie (zázemie obce), kde sa škola nachádza, prípadne územie d'alších obcí, z ktorých deti do tejto školy dochádzajú (Kancír, Madziková, 2003). Postupne sa poznávaný región zväčšuje, pričom hovoríme o širšom okolí obce, často bez presného vymedzenia, niekedy $\mathrm{s}$ využitím administratívnych (napr. katastrálne územie obce, okres, kraj, oblast', štát, zoskupenie štátov, svetadiel) alebo prírodných hraníc (napr. geomorfologický celok, povodie, resp. úmorie, klimatická oblast', bioklimatické pásmo, kontinent). Najvýstižnejšie je miestna krajina charakterizovaná ako humánnogeografický región nižšieho rádu, t. j. nodálny región, ktorého stredisko s určitými zariadeniami (pracoviská, služby) viaže na seba obce v jeho zázemí. Miestnu oblast' vel'kých miest tvorí vlastné mesto a jeho zázemie. Môžeme povedat', že miestna krajina je areál platnosti denného rutinného rytmu človeka v prostredí (Kandráčová, Michaeli, 1997). Predstavuje tú čast' prostredia človeka, ktorá je na styku zóny bezprostredného a nepretržitého zmyslového poznávania (napr. dom, miestna štvrt', obec so základnou vybavenost'ou, so zónou vnímanou periodicky, t. j. obec s väčším komplexom vybavenosti). Vel'kost'ou ju môžeme zaradit' na rozhranie lokálnej a regionálnej dimenzie. 
Časové hl'adisko sa podl'a Tomčíkovej (2010) odráža v životných skúsenostiach, ktoré nadobudol jedinec počas svojho života v určitej miestnej krajine (evolučný potenciál). Prejavuje sa to určitou citovou (mentálnou) väzbou l'udí, ktorí žijú v miestnej krajine. Táto je pre nich pocitom domova, bezpečia a dôvernosti. Tomu zodpovedá aj určitý spôsob vnímania miestnej krajiny jedincom a jeho správaním sa v nej. Pre človeka žijúceho na konkrétnom mieste majú zmysel nielen fyzické objekty tvoriace toto miesto, ale aj udalosti, ktoré tu prežil v minulosti. Toto hl'adisko najlepšie vystihuje latinský pojem „genius loci“ (duch miesta). Obsahuje v sebe jednotu „genia regionis“ (ducha krajiny) a „genia populi“ (ducha l'udí, príp. spoločnosti), ktorá je v geografii miestnej krajiny vel'mi dôležitá.

Didaktické hl'adisko miestnej krajiny má pri vyučovaní geografie vel'ký význam. Hlbšie poznanie miestnej krajiny je nielen ciel'om, ale aj prostriedkom geografického vzdelávania. Konkrétne geografické javy a ich vzt’ahy v miestnej krajine slúžia ako model na pochopenie všeobecne platných súvislostí a pravidelností. Podrobnejšie pozorovanie miestnej krajiny rozvíja u žiakov záujem o ňu, umožňuje l'ahšie pochopenie dynamických premien krajiny, osobitosti a vzt'ahy medzi človekom a krajinou. Žiak získaním skúseností pri riešení problémov v jednoduchšej, známej miestnej krajine (napr. vidiecka obec) môže potom l'ahšie a úspešnejšie postupovat' pri riešení problémov komplikovanejšej, menej známej mestskej obce či väčšieho regiónu (Tomčíková, 2010). Miestna krajina je tá čast' reálneho sveta, ktorá nás obklopuje od útleho detstva, ponúka nám možnosti kognitívneho rozvoja, podnety pre emocionálny rozvoj, formovanie názorov, je bránou pri poznávaní vzdialenejších krajín v časovo-priestorovej dimenzii, ktorú možno využívat' v medzipredmetových vzt'ahoch.

\section{Postavenie geografie miestnej krajiny v školskom vzdelávacom programe}

Na Slovensku podla obsahovej reformy školstva platnej od 1. septembra 2008 a Štátneho vzdelávacieho programu je predmet geografia zaradený do vzdelávacej oblasti Človek a spoločnost' (spolu s predmetmi dejepis a občianska náuka). Obsah učiva geografie sa s výnimkou 5. ročníka opiera o spoznávanie jednotlivých regiónov Zeme, pričom nadväzuje na základy geografických poznatkov $\mathrm{z}$ vlastivedy.

Vo vlastivede v 3. a 4. ročníku žiaci názorne spoznávajú hlavné rysy obce a jej najbližšieho okolia, učia sa chápat' v elementárnej rovine základné väzby medzi prírodou a spoločnost'ou $\mathrm{v}$ miestnej krajine. Nakol'ko vlastiveda predstavuje elementárnu úroveň geografickej výchovy, má vel'mi blízky vzt’ah ku geografii. S vyučovaním geografie ju však nemôžeme úplne stotožňovat', pretože vlastiveda je komplexným videním sveta $\mathrm{v}$ geografickom aj historickom kontexte $\mathrm{s}$ výraznou výchovnou funkciou.

Predmet geografia sa vyučuje v 5. ročníku v rozsahu 2 vyučovacie hodiny týždenne (66 hodín ročne) a v 6., 7., 8. a 9. ročníku po 1 vyučovacej hodine 
týždenne (33 hodín ročne). Tento stav platný od 1. septembra 2015 predstavuje zvýšenie rozsahu týždennej výučby o 1 hodinu (bola pridaná do 5. ročníka) v porovnaní s predchádzajúcim obdobím (od roku 2008). Zmenilo sa tiež poradie svetadielov vo vyučovaní regionálnej geografie v 6. až 9. ročníku, geografia Slovenskej republiky sa presunula z 9. do 8. ročníka ZŠ. Učivo miestnej krajiny je vo väššej alebo menšej miere predmetom záujmu vzdelávania geografie v každom ročníku. Malá časová dotácia pre geografiu však znižuje možnosti častejšieho začlenenia geografie miestnej krajiny do vyučovacieho procesu tohto predmetu.

Vd’aka školskému vzdelávaciemu programu sa dá počet vyučovacích hodín geografie $\mathrm{v}$ jednotlivých ročníkoch navýšit' a toto posilnenie využit' o zaradenie učiva o miestnej krajine. Objektívne treba však dodat', že v školách často nie je vôla navýšit počet hodín geografie do školského vzdelávacieho programu, k posilneniu hodín dochádza hlavne v prospech cudzích jazykov alebo d’alších predmetov, ktoré štátny vzdelávací program definuje ako prierezové témy. Potom sa nemožno čudovat', že chýba priestor na tvorivost' a nedostatok času na učivo o miestnej krajine spôsobuje absenciu nadšenia nielen na strane učitel'ov, ale aj na strane žiakov.

\section{Ciele a obsah učiva geografie miestnej krajiny na základnej škole}

Zachovanie kontinuity poznávania miestnej krajiny predpokladá zaradenie regionálnych poznatkov do celého systému vyučovania geografie využívaním konkrétnych príkladov z miestnej krajiny. Konkrétne geografické javy a ich vzt’ahy v miestnej krajine tak poslúžia ako model pre pochopenie všeobecne platných vertikálnych, horizontálnych vzt'ahov a geografických zákonitostí. Informácie o miestnej krajine treba prispôsobit' psychologickým zvláštnostiam chápania žiakov, rešpektovat' prirodzený vývin detí a opierat' sa vo vyučovaní o ich skúsenosti. Primerane veku by sa mala stupňovat' náročnost' úloh, ktoré majú žiaci zvládnut', ako aj náročnost' a množstvo informácií o miestnej krajine.

V 5. ročníku získavajú žiaci základné vedomosti z geografie, ktoré sa majú podávat' žiakom motivačným spôsobom a vysvetl'ovat' $v$ praktickej rovine. $\mathrm{S}$ geografiou miestnej krajiny sa stretávame v dvoch tematických celkoch: Mapa a glóbus, Najkrajšie miesta na Zemi, ktoré vytvorila príroda.

V tematickom celku Mapa a glóbus sa žiaci učia používat' mapu vo svojom okolí, pracujú s turistickou mapou, automapou, plánmi mesta a tematickými mapami. Taktiež si osvojujú orientáciu v teréne bez mapy, určovanie svetových strán a ich rôzne možnosti určenia. Žiaci sa naučia čítat mapy, získavat' z nich informácie a aplikovat' ich vo svojom okolí. Ak sa rozvíjaniu týchto zručností bude venovat' dostatok času a ak sa to prepojí s vyučovaním v triede, žiaci budú mat' dobrý základ na využívanie mapy pri získavaní informácií o krajine, v ktorej bývajú.

V tematickom celku Najkrajšie miesta na Zemi, ktoré vytvorila príroda; majú žiaci pochopit’ ako fungujú jednotlivé zložky krajiny danej oblasti, majú 
porozumiet' a všimnút' si odlišnosti krajiny. Dôležité je, aby si žiaci uvedomili vzt’ahy a vzájomné pôsobenie jednotlivých zložiek krajiny, čo si najlepšie dokážu predstavit' práve v mieste svojho bydliska. Môžu napríklad opisovat' počasie v určitom časovom úseku, poznávat' rastlinstvo miestnej krajiny, zistit', aké druhy stromov rastú v okolí a prečo. Ak využijú žiaci poznatky z dejepisu, môžu skúmat', aký bol vývoj sídla v minulosti, akým smerom sa rozrastalo, ktoré časti sa nezachovali, ktoré pamiatky majú v miestnej krajine najväčšiu hodnotu a prečo. $\mathrm{Na}$ určitom území v okolí školy môžu zistit', zakreslit' a popísat' všetky zložky krajiny a vzt'ahy medzi nimi.

V 8. ročníku tvorí vel'kú čast' roka tematický celok Slovensko. V rámci Slovenska je možnost' venovat' sa aj geografii miestnej krajiny. Práve tu je možnost' navrhovanú koncepciu využit', nakol'ko doposial' vyučovanie miestnej krajiny zodpovedá tradičným geografickým charakteristikám, ktorých t’ažisko je v prírodných pomeroch, miestopise a hospodárskom prehl'ade.

Ďalší priestor pre vyučovanie geografie miestnej krajiny poskytuje aj prierezová téma Regionálna výchova a tradičná l'udová kultúra, ktorá môže byt' prostredníctvom kurikulárnej reformy Štátneho vzdelávacieho programu zaradená do volitel'ných vyučovacích predmetov, ako je napr. regionálna výchova alebo regionálny dejepis. Ciel'om je pritom vytvárat' u žiakov predpoklady na pestovanie a rozvíjanie citu ku krásam svojho regiónu, prírody, stavitel'stva, l’udového umenia a spoznávanie kultúrneho dedičstva našich predkov. Edukačná činnost' je zameraná na to, aby žiaci $\mathrm{v}$ rámci regionálnej výchovy poznali históriu, ale aj súčasnost' vlastnej obce či mesta.

\section{Navrhovaná koncepcia vyučovania geografie miestnej krajiny}

Základom tejto koncepcie je miesto a vzt'ah žiaka k tomu miestu (ako to miesto žiaka ovplyvňuje). Žiak tu žije, identifikuje sa s miestom, stretáva sa $\mathrm{s}$ d’alšími l'ud'mi, vzdeláva sa (hl'adá, zhromažd'uje si užitočné informácie, získava skúsenosti). Vytvára si akúsi mentálnu mapu, v ktorej je dôležité vnútorné priestorové znázornenie miesta, ktoré dosial' poznal.

Agnew (1987) popísal tri základné znaky miesta:

- poloha (location) - určitý bod na povrchu Zeme,

- charakteristika miesta (locale) - miesto, kde existujú každodenné vzájomné vzt'ahy,

- význam miesta (sense of place) - subjektívne vnímanie miesta jedincom.

Štúdium geografie miestnej krajiny (tab. 1) sa začína jej lokalizáciou na Zemi, ktorá môže byt' opísaná dvoma rôznymi spôsobmi. Absolútna poloha je opísaná geografickými súradnicami. Relatívna poloha je opísaná porovnávaním $\mathrm{s}$ niečím iným, napr. poloha vzhl'adom k oceánom, poloha $\mathrm{v}$ rámci ekonomického systému. 
Tab. 1: Štúdium miestnej krajiny ako miesta

Table 1: The study of the local country as a place

\begin{tabular}{|c|c|c|}
\hline & miesto & miestna krajina \\
\hline \multirow{6}{*}{$\begin{array}{l}\mathrm{r} \\
\mathrm{e} \\
\mathrm{a} \\
\mathrm{l} \\
\mathrm{i} \\
\mathrm{t} \\
\mathrm{a}\end{array}$} & $\begin{array}{c}\text { lokalizácia miesta } \\
\text { (location ) }\end{array}$ & geografická poloha \\
\hline & \multirow{5}{*}{$\begin{array}{c}\text { chatakteristika } \\
\text { miesta } \\
\text { (locale) }\end{array}$} & príroda a krajina \\
\hline & & história a kultúra \\
\hline & & obyvatel'stvo a sídla \\
\hline & & hospodárstvo \\
\hline & & životné prostredie \\
\hline & & NORMA \\
\hline $\begin{array}{l}p \\
r \\
e\end{array}$ & \multirow{3}{*}{$\begin{array}{l}\text { význam miesta } \\
\text { (sense of place) }\end{array}$} & $\begin{array}{c}\text { city, postoje, skúsenosti, } \\
\text { zážitky }\end{array}$ \\
\hline $\begin{array}{l}d \\
s \\
t\end{array}$ & & $\begin{array}{l}\text { prednosti, hodnoty, } \\
\text { identita }\end{array}$ \\
\hline$v$ & & fantázia \\
\hline & enosti) $\rightarrow$ súc & $\rightarrow$ budúcnost' (očakávania) \\
\hline
\end{tabular}

Zdroj: Upravené podla Vávra (2012) a Agnew (1987)

Charakteristika miesta: Tradičný prístup charakterizovat' miestnu krajinu pomocou hettnerovskej schémy - prvkami prírodného prostredia (reliéf, klímu, vodstvo, pôdy, rastlinstvo a živočíšstvo) a l'udských aktivít (obyvatel'stvo, 
osídlenie, ekonomiku, dopravu, cestovný ruch, služby) vedie k istej šablónovitosti, ktorá znemožňuje pochopenie špecifických čŕt a odlišností regiónu, jeho jedinečnosti (Madziková, 2004). Preto pri aplikácii tohto prístupu vo vyučovaní geografie miestnej krajiny netreba dodržat' proporcionalitu v zastúpení jednotlivých prvkov výrezu geografickej sféry, ale je potrebné kriticky zdôraznit' tie, ktoré sa na špecifikách regiónu významne podiel'ajú (nimi sa odlišuje toto miesto od iného miesta na Zemi) a naopak zredukovat' tie, ktoré majú všeobecnejší charakter. Všetky tieto prvky tvoria štruktúru systému - štruktúru miestnej krajiny. Sú vzájomne prepojené a plnia svoje funkcie (napr. funkcia reliéfu na klímu, reliéfu na povrchové vodstvo, klímy pre vegetáciu, reliéfu pre cesty, ciest pre osady).

Hettnerovská schéma je podl'a Kühnlovej (1997) pre potreby vyučovania pomerne náročná a možno ju upravit' spojením jednotlivých prvkov do 6 väčších komplexov - geografická poloha, príroda a krajina, história a kultúra, obyvatel'stvo a sídla, hospodárstvo, životné prostredie. Vyučovanie by sa malo zakladat' na regionálnych poznatkoch a pochopení histórie, súčasnosti i perspektív vývoja do budúcnosti (aký mala vzhl'ad, aké boli postupné zásahy človeka a aké sú súčasné problémy v krajine). Je vhodné objasnit príčiny rozmiestnenia aktivít, ich špecializáciu vo vzt’ahu k podmienkam v krajine, ich vplyv na vzhl'ad krajiny, stav životného prostredia a estetickú hodnotu krajiny. Vyučovanie geografie miestnej krajiny treba rozšírit’ o geografické hodnotenie krajiny z hl'adiska kvality životného prostredia (program obnovy mesta/dediny, rozmiestnenie hospodárskych aktivít $\mathrm{v}$ krajine), regionálneho plánovania (funkčné využitie územia a jeho zmeny, stabilita územia) a historického vývoja (výrobné tradície, kultúra a zvyky, vzhlaad krajiny ako historický dokument doby).

Význam miesta: Miestna krajina je žiakom blízka, lebo v nej žijú. Tým, že ide o prostredie, ktoré je žiakom známe, vyučovanie by sa malo zakladat' na ich skúsenostiach, toto miesto sa vrýva do ich predstáv. Identita je vlastnost', ktorá sa viaže $\mathrm{k}$ l'ud'om, $\mathrm{k}$ ich subjektívnym pocitom, ktoré sú založené na ich každodenných skúsenostiach a zážitkoch. Miestna krajina môže tiež podnecovat' fantáziu, predstavivost' a tiež môže znamenat' miesto, pomocou ktorého žiak porovnáva a predstavuje si ostatné miesta. Vzt’ah k miestu a k l'ud’om, ktorí tam žijú, je vel'mi významnou podstatou integrity jedinca, ktorý pri konfrontácii $\mathrm{s}$ inými hodnotí a chápe miesto inak. Hodnotí ho inak práve vd’aka osobnému vývoju, poznaniu a skúsenostiam s miestom, v ktorom žije. Hovoríme o geografickom myslení a o skúsenostiach jedinca i komunity, ktoré sa k miestu viažu (Vávra, 2010).

Ked' však chceme, aby žiaci pochopili miestnu krajinu, musia ju študovat' v širších súvislostiach (obr. 1). Položíme žiakom napríklad otázky: Ako reliéf ovplyvňuje počasie v meste? Ako rieka vytvorila dolinu, v ktorej sa nachádza naše mesto? Aký vplyv má supermarket na miestnu ekonomiku? Ked' budeme chciet', aby odpovedali na tieto otázky, musia uvažovat' o regióne, ktorý obklopuje miestnu 
krajinu. Nasledujú otázky: Môže sa počasie v rôznych častiach mesta líšit? Čo má vplyv napríklad na rôznu teplotu vzduchu v zastavanej oblasti v centre mesta a v oblasti, ktorá na jeho okraji susedí s lesom? Ked' začneme študovat' krajinu v regionálnej dimenzii, zistíme, že je dôležitá aj kontinentálna a planetárna dimenzia. Napríklad počasie v regióne závisí od všeobecnej cirkulácie atmosféry, ale aj od vzdialenosti od mora, povrch a geologické zloženie závisia od horotvorných procesov, ktoré $\mathrm{v}$ Európe prebiehali $\mathrm{v}$ minulosti a pod. Ked' chceme charakterizovat' miestnu krajinu, musíme vychádzat' z poznatkov jej polohy $\mathrm{v}$ rámci regiónu, štátu, kontinentu, dokonca aj polohy na Zemi (Tomčíková, Rakytová, 2018). Poznávanie miestnej krajiny by malo byt' detailnejšie v závislosti od dimenzie (vyšší územný celok, miestny región, obec, mestská štvrt', sídlisko).

Obr. 1: Štúdium miestnej krajiny v priestore

Figure 1: The study of local landscape in space

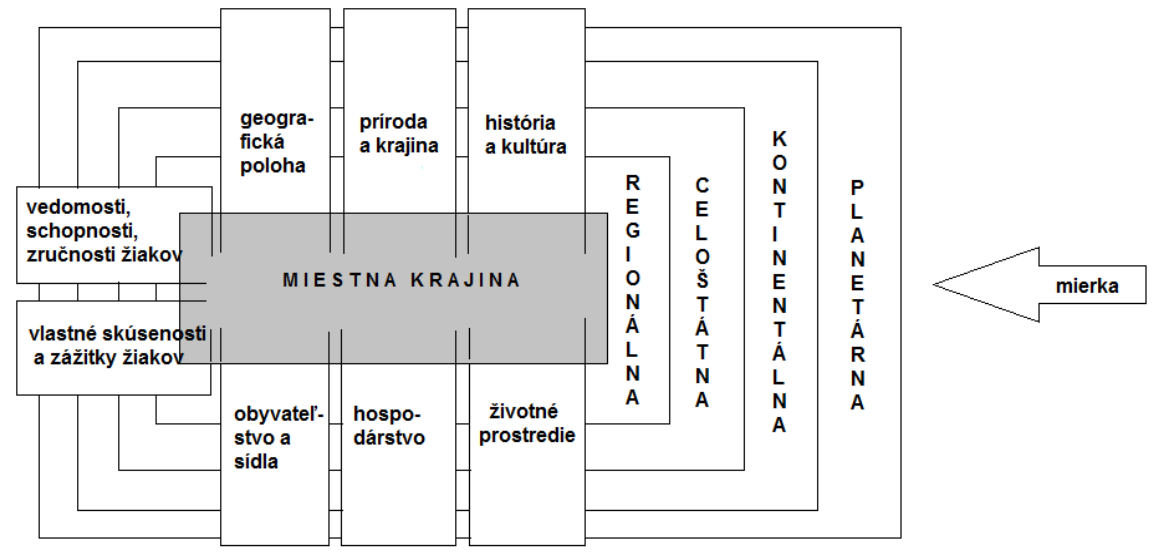

\section{Záver}

Miestna krajina je tá čast' reálneho sveta, ktorá žiakov obklopuje od útleho detstva, geografické poznatky sú teda vel'mi úzko späté s praktickým životom. Práve vo vyučovaní geografie miestnej krajiny musí učitel' položit' dôraz na afektívne ciele a prostredníctvom nich dôjde aj $\mathrm{k}$ upevneniu a naplneniu kognitívnych ciel'ov u žiakov. Poznanie faktov je samo o sebe bezcenné bez zvládnutia schopnosti syntetizovat', integrovat' a hodnotit'. Ked' žiaci o novom poznatku uvažujú, zapájajú sa do diskusie, hl’adajú riešenia, vtedy sa stanú ich nové skúsenosti základom poznania. Miestnu krajinu žiaci poznajú, môžu prezentovat' svoje skúsenosti a zážitky, konfrontovat' svoje vlastné skúsenosti so svojimi spolužiakmi, učitel’om, autormi doplnkových informačných prameňov. 
Vyučovanie geografie miestnej krajiny poskytuje vel'a možností využívat' progresívne vyučovacie metódy a formy. Žiaci by nemali byt' len pasívnymi prijímatel'mi informácií, ale mali by pracovat' samostatne, získavat' informácie vlastnou činnost'ou, zvlášt' ked' pracujú s lokálnymi zdrojmi informácií, často im vel'mi známymi. Žiaci postupne spoznávajú miestnu krajinu, jej históriu, kultúru, prírodné krásy a zaujímavosti, čím získavajú pocit hrdosti a spolupatričnosti $\mathrm{k}$ svojmu rodnému kraju, vlasti. Môžu sa tu prejavit' aj slabší žiaci samostatným riešením problémov, schopnost'ou hodnotit' javy z reálneho života.

Geograficky mysliet' znamená porozumiet' svetu, odhalit' priestorové súvislosti medzi miestami a mierkami. Podl'a Matloviča a Matlovičovej (2015) je miesto jedným z kardinálnych konceptov geografie. Žiaci môžu poznávat' svet cez miesta a to pomocou percepcie a skúseností. Novou výzvou pre vzdelávací proces je preto učit' o miestach a regiónoch cez vzt'ah obyvatel'ov $\mathrm{k}$ danému miestu. Treba však upozornit', že ked' chceme, aby žiaci pochopili miestnu krajinu ako miesto, musia ju študovat' $v$ širších súvislostiach vo vzt'ahoch s priestorom, ktorý ju obklopuje.

\section{Literatúra}

AGNEW, J. 1987. Place and politics: the geographical mediation of state and society. In JSTOR by Royal Geographical Society. vol.13, no. 2, pp. 251-253.

KANCÍR, J. - MADZIKOVÁ, A. 2003. Didaktika vlastivedy. Prešov: Universum, 2003. 216 s. ISBN 978-80-8068-760-1.

KANDRÁČOVÁ, V. - MICHAELI, E. 1996. Mikrogeografia v edukácii, výskume a pre prax. In Krajina východného Slovenska v odborných vedeckých prácach. Prešov: Prešovská univerzita, 1996. s. 265-285.

KÜHNLOVÁ, H. 1998. Zemepis místního regionu - priroda. kultura a životni prostredi. In Geografické rozhledy. roč. 7, č. 4, s. 116-119.

MADZIKOVÁ, A. 2004. Miestny región vo vyučovaní geografie na gymnáziu. In Prírodné vedy. In Folia Geographica 7. Prešov: Prešovská univerzita v Prešove, 2004. ISBN 80-8068-270-4, s. 247-291.

MATLOVIČ, R. - MATLOVIČOVÁ, K. 2015. Geografické myslenie. Prešovská univerzita. Fakulta prírodných a humanitných vied. Prešov, 2015. $321 \mathrm{~s}$.

NOGOVÁ, M. 2016. Miesto ako príklad rozvíjania geografického myslenia žiakov metódou Flow learning na príklade vzdelávacieho centra v národnom parku Donau-Auen. In Geografické myšleni jako aktuální společenská výzva. České Budějovice: Jihočeská univerzita, 2016. ISBN 978-80-7394-619-7, s. 283-288.

SCOFFHAM, S. 2011. Core knowledge in the revised curriculum. In Geography. vol. 96, no. 3, pp. 124-129.

TOMČÍKOVÁ, I. 2010. Miestna krajina vo vyučovaní vlastivedy a geografie na základnej škole. In Geographia Cassoviensis. ISSN 1337-6748, 2010, roč. 4, č. 1, s. 159-163. 
TOMČÍKOVÁ, I. 2013. Kognitívne ciele vo vyučovaní geografie miestnej krajiny na základnej škole. In Geographia Cassoviensis. ISSN 1337-6748, 2013, roč. 7, č. 1 , s. 157-162.

TOMČÍKOVÁ, I. 2017. Experience-based learning in teaching of the local landscape. In Useful Geography: Transfer from Research to Practice: Proceedings of 25th Central European Conference, 12th-13th October 2017, Brno. Masarykova univerzita, 2017. ISBN 978-80-210-8907-5, s. 91-102.

TOMČÍKOVÁ, I. - RAKYTOVÁ, 2018. Geography of local landscape in the educational process in primary schools in Slovakia. In European Journal of Geography. ISSN 1792-1341, 2018, vol. 9, no. 1, pp. 49-61.

VÁVRA, J. 2010. Jedinec a miesto, jedinec v místě, jedinec prostřednictvím místa. In Geografie. roč. 115, č.4, s. 461-478.

VÁVRA, J. 2012. Geografické myšleni v českém geografickém vzdělávaní. Př́íspěvek přednesený na 4. workshopu geografického vzdělávání v Liberci, 17. ledna 2012. s. 1-9.

\section{CONCEPTION OF TEACHING OF LOCAL LANDSCAPE GEOGRAPHY IN PRIMARY SCHOOL}

\section{Summary}

The local landscape is the part of the real world that surrounds pupils from childhood and the geographic knowledge is therefore very closely related to practical life. Just in teaching geography of the local landscape, the teacher has to put emphasis on the affective goals, through which the cognitive goals will be strengthened and fulfilled. The fact-finding is worthless without the ability to synthesise, integrate and evaluate. When pupils think about new knowledge, they engage in discussion and seek solutions, only then, their new experiences will be base for their knowledge. Pupils recognise the local landscape; they can present their experiences and confront their own experiences with their classmates, teacher, and authors of additional sources of information.

Teaching geography of the local landscape provides many opportunities to use progressive teaching methods and forms. Pupils should not only be passive recipients of information but they should work independently to acquire information by their own activities, especially when they work with local sources of information often familiar to them. Pupils gradually become familiar with the local landscape, its history, culture, natural beauty and interest, thus gaining a sense of pride and belonging to its native land, native country. In this case, weaker pupils with self-solving problems, ability to evaluate real life phenomena can show their abilities.

Geographical thinking means to understand the world, to discover spatial connections between places and scales. According to Matlovič and Matlovičová, 
the place is the cardinal concept of geography. Pupils can explore the world through places, using perceptions and experiences. The new challenge for the learning process is therefore to learn about places and regions through the relationship of the people to the place. However, it should be noted that when we want pupils to understand the local landscape as a place, they need to study it in a broader context. In the space that surrounds them.

Based on these ideas, we designed the conception of teaching the geography of the local landscape, in which we put emphasis on localization (location), spatial thinking, but also on the importance of the local landscape for pupils. The basis of this conception is the place and the relationship of pupils to that place (as it affects pupils). The study starts with the localization of the local landscape (described by geographical coordinates and position relative to some other location), followed by the characteristics of the local landscape (nature and landscape, history and culture, population and settlements, economy and the environment). These complexes cannot be studied separately but in contexts. It is appropriate to clarify the reasons for the deployment of activities, their specialization in relation to the conditions in the country, their impact on the landscape, the state of the environment and the aesthetic value of the landscape. The local landscape is the place where pupils live, have a relationship with and they recognize through their own experience. Pupils identify with it; there is a certain emotional point between them and this place, whose importance they are aware of for their further development (sense of place). The conception includes not only the current state of the local landscape, but also the past (through personal experiences, history studies) and the future (expectations and intentions).

RNDr. Ivana Tomčíková, PhD.

Katedra geografie PF KU v Ružomberku

Hrabovská cesta 1, 03401 Ružomberok

E-mail: ivana.tomcikova@ku.sk 